\title{
Possibilities for achieving the vision of near net zero emission in building sector in Bosnia and Herzegovina
}

\author{
Sandra Martinovic, Rejhana Muhamedagic, Azrudin Husika \\ Department of Energetics/Faculty of Mechanical Engineering, University of Sarajevo, Sarajevo, Bosnia and Herzegovina \\ Email address: \\ s.martinovic@mef.unsa.ba (S. Martinovic),muhamedagic@mef.unsa.ba (R. Muhamedagic), husika@mef.unsa.ba (A. Husika)
}

\section{To cite this article:}

Sandra Martinovic, Rejhana Muhamedagic, Azrudin Husika. Possibilities for Achieving the Vision of Near Net Zero Emission in Building Sector in Bosnia and Herzegovina. American Journal of Environmental Protection. Vol. 3, No. 5, 2014, pp. 217-224.

doi: 10.11648/j.ajep.20140305.12

\begin{abstract}
Increase of greenhouse gases concentration in the atmosphere, mainly carbon dioxide, which leads to global warming, indicates the need to take actions to reduce use of energy from carbon sources. The building sector is the largest consumer of energy, and thereby the largest emitter of greenhouse gases. In this paper the possibilities of achieving "near net zero emission" vision, in the residential sector, by the year 2050, were analysed. The necessary policies and technical energy efficiency measures were analysed, that could be applied in the building sector in Bosnia and Herzegovina by 2050 . Large amount of energy is used for space heating and hot water, mainly from fossil fuels, which significantly contributes to air pollution and global warming. Specific energy consumption for space heating in Bosnia and Herzegovina is several times higher than in EU countries with the similar climate conditions. Therefore, it is necessary to reduce energy consumption significantly, ie to increase energy efficiency. It is also necessary to deploy the potential of renewable energy use in buildings and to use buildings as energy producers. In this way, in the long term, energy costs in buildings would be significantly reduced, as well as dependence on energy imports and the need for building of new capacities for energy generation. From other side, employment would be increased while emissions of pollutants and greenhouse gases would be reduced. In this paper, due to the availability of reliable data on energy consumption for the Sarajevo Canton, the necessary policies and measures to promote energy efficiency were analysed, that could be applied in the residential sector in the Sarajevo Canton.
\end{abstract}

Keywords: Buildings, Energy Efficiency, Renewable Energy Sources, Greenhouse Gases

\section{Introduction}

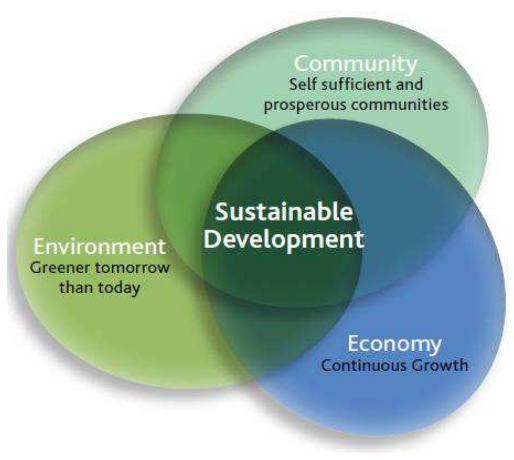

Figure 1. The scheme of Sustainable Development [1]

Improved consumption in all the segments of human life leads to the enormous deprivation of the natural resources. Consequently, there is a necessity for the reduction of non renewable natural resources consumption, actually the aspiration to the sustainable development.

The basic representation of the symbiosis between man and the nature is the ideology of sustainable development (Figure 1). Sustainable development can be defined in numerous ways. Sometimes, this term is used only to accentuate the importance of continuing and stable economic improvement. It can also define environmental goals. Sustainable development can be defined as the development which is sufficient enough for human needs of the current generations, without causing any problems for the future generations to accomplish their needs [2]. Being sustainable also concerns technology and the capital.

The term "sustainability" makes us imagine numerous scenarios for attaining the sustainable society. Social systems are complex and nonlinear. However, there is a tendency of putting those systems to a certain models, in order to be easily understandable and in order to be able to foresee their 
functions. Academic tradition is the main reason of it, where the scientists try to make the social laws more similar to the nature ones. On the other hand, the complexity of social systems requires a wider perspective, which includes the entire system and uses the back casting method, based on the principles of sustainability. This could be the chance for achievement of better future. In this process, interdisciplinary approach is the one, which is needed to be applied for better creation of the basic frame, which enables achievement of good results. The changes of the working process, necessary for creation of sustainable society, can be mutually implemented.

\section{Research Method}

During the last few decades, faster economic and population growth has damaged environment in the form of depletion of ozone layer, climate changes, overuse of fossil fuels and many other consequences, which will surely, in these conditions, be multiplied. Scientists agree that radical measures should be done in order to soothe the negative consequences on environment.

Creation and implementation of radical measures, requires interdisciplinary approach, actually the cooperation of all sectors of the society. The transformation process must start at the level of every individual, reconsidering its own behavior and relation to the nature, its attitudes, as well as its consumption. So far, we have been using the working principle based on the analysis of the problem in the present and an attempt of solving it in the future from the present point of view (forecasting method). However, in the world of constant changes, the mutual perspective or the global vision is something necessary. From the perspective of desired future, finding the way of action in the very present is of crucial importance. This approach is called backcasting method. It is used to describe a future desired scenario, and to value its reason. Objectives are created for a longer period of time, about 50 years [3]. The longer period of time, the greater insecurity and worse control over the possible future scenarios, therefore the vision of future is better defined using the principle of sustainability, unlike specifications for the required period.

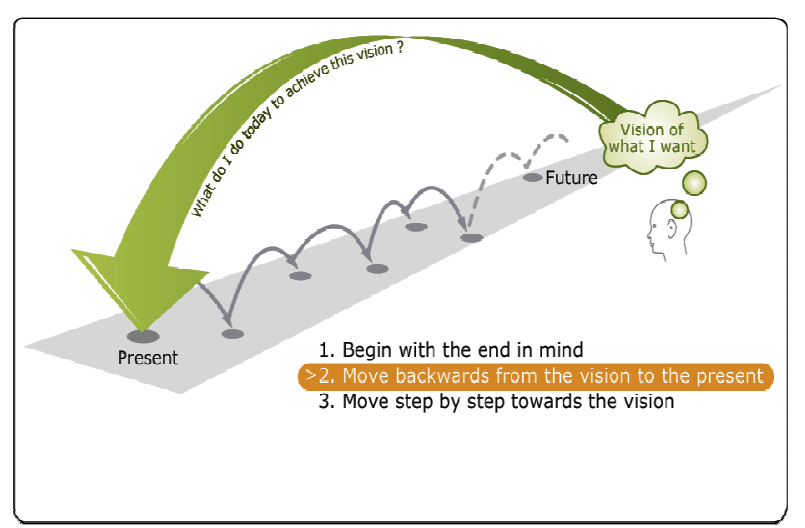

Figure 2. Applying the Backcasting Method [4]
The backcasting method is a chance to escape the reality and imagine the vision of future, without any limits of a vision, with realistic possibilities of its realization. This method is usually more effective than the forecasting one, especially in the period of fast and radical changes, because it has no intention of revealing the future, but to analyze more possible future scenarios, and to choose the best variants, as well as to define the steps of realization of the vision (Figure 2).

\section{Application of Backcasting Method on Energy Consumption in Buildings}

Functioning of cities is based on the constant flows of energy, natural resources, services, people, information, etc. It means it cannot be seen as a simple closed system. All the flows mentioned above are needed for human needs, but it may cause problems such as: air pollution, traffic jams and waste materials. According to the method of trend, it is supposed that cities in the future will face the problems similar to ones of the present, but having in mind that those problems will be more intensive, unless the actions for the development of sustainable cities are implemented.

The concept of the sustainable development requires a good strategic planning, analysis of more factors, including the past, present and vision of the future, creation and realization of the measures, technology development and raising awareness of individuals. In this paper, the concept of the sustainable development will be applied in Sarajevo Canton on energy consumption in buildings. The concept based on the vision of the sustainable cities in the future will be tendered, but since it requires significant changes, the backcasting method will be used. The focus of this work is on reduction of carbon dioxide emission, applying new technologies, sustainable energy resources and energy efficiency [5, 6].

The vision of the energy consumption in housing in Sarajevo Canton (already mentioned in this paper), whose possibility of realization is important to examine, is 40 to $50 \%$ less carbon dioxide emission in 2050 in comparison to the present emission.

\subsection{Current Situation of Energy Consumption in Housing in Sarajevo Canton}

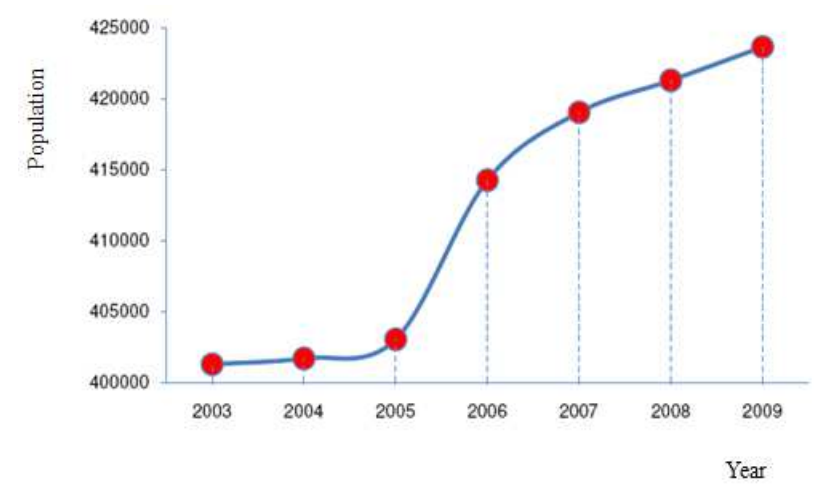

Figure 3. Population growth in Sarajevo Canton [7] 
According to the available data on consumption of specific energy sources, the analysis of energy consumption has been made for the residential sector in Sarajevo Canton. The first analysis of energy consumption is made for 2008. In the middle of 2008, 421.289 citizens lived in Sarajevo Canton and 304.614 of them lived in the City of Sarajevo. Population in Sarajevo Canton records a growth rate of $1,2 \%$ annually in the period from 2003 to 2010, and from 2003 to 2008, the growth rate was $0,95 \%$ [8] (Figure 3).

Total floor area of residential buildings in Sarajevo Canton in 2008 was $11.354 .270 \mathrm{~m}^{2}$. According to data for 2008, there were 180.265 residential buildings in Sarajevo [7].

Table 1 shows how many residential buildings make an individual housing (private houses), collective housing (households not connected to the district heating plants), and collective housing (households connected to the district heating plants).

Table 1. Types of households in the residential sector in Sarajevo Canton

\begin{tabular}{|c|c|c|}
\hline \multicolumn{3}{|c|}{ Households not connected to the district heating plants } \\
\hline Housing & $\begin{array}{l}\text { Number of residential } \\
\text { buildings }\end{array}$ & $\begin{array}{l}\% \text { out of complete } \\
\text { number of residential } \\
\text { buildings }\end{array}$ \\
\hline Collective housing & 29.748 & 17 \\
\hline Individual housing & 105.238 & 58 \\
\hline \multicolumn{3}{|c|}{ Households connected to the district heating plants } \\
\hline Housing & $\begin{array}{l}\text { Number of residential } \\
\text { buildings }\end{array}$ & $\begin{array}{l}\% \text { out of comp } \\
\text { lete number of residential } \\
\text { buildings }\end{array}$ \\
\hline Collective housing & 45.279 & 25 \\
\hline
\end{tabular}

The structure of energy consumption in residential sector buildings is: $20 \%$ for preparation of domestic hot water, $7 \%$ for electrical devices, $6 \%$ cooking, 5\% lighting, 2\% cooling, $60 \%$ heating [7].

Figure 4 shows the share of electrical energy consumption in households according to the type of usage. The calculation was based on the available data on total energy consumption in this sector.

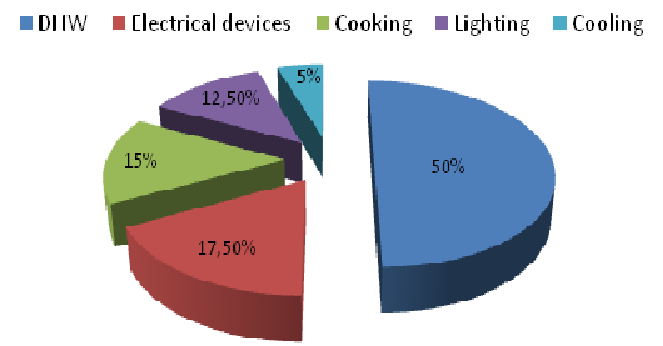

Figure 4. Electrical energy consumption according to the usage

In 2008, energy of 1.680,25 GWh was delivered to the residential sector in Sarajevo Canton, which is: electricity of $554,42 \mathrm{GWh}$ or $32,9 \%$, natural gas of $967,95 \mathrm{GWh}$ or $57,6 \%$, solid fuels of $153,37 \mathrm{GWh}$ or $9,12 \%$ and oil derivatives of 4,5 GWh or $0,27 \%[7,9,10]$.

Table 2 shows the energy consumption in 2008 in the residential sector.

Table 2. Energy consumption in 2008 in the residential sector in Sarajevo Canton [7, 9, 10]

\begin{tabular}{|c|c|c|c|c|c|c|c|c|c|}
\hline \multicolumn{2}{|c|}{ Residential buildings [MWh] } & \multicolumn{4}{|c|}{ Private houses [MWh] } & \multicolumn{4}{|c|}{ District heating system [MWh] } \\
\hline Electricity & Gas & Electricity & Gas & Wood & Coal & Electricity & Gas & Light fuel oil & Heavy fuel oil \\
\hline $76.668,6$ & $109.680,8$ & $353.093,3$ & $362.541,4$ & $79.422,5$ & 73.950 & $124.666,6$ & $495.733,3$ & 2.651 & $1.850,8$ \\
\hline
\end{tabular}

Table 3 shows the estimated carbon dioxide emission from residential building.

Table 3. Emissions of carbon dioxide in Sarajevo Canton in 2008

\begin{tabular}{|c|c|c|c|c|}
\hline \multirow{2}{*}{2008} & \multirow{2}{*}{ Coefficient of $\mathrm{CO}_{2}$ emissions [t/MWh] } & \multicolumn{3}{|c|}{ Mass of $\mathrm{CO} 2$ emitted, [t/a] } \\
\hline & & Residential buildings & Private houses & District heating system \\
\hline Gas & 0,202 & $22.155,52$ & $65.513,95$ & $100.138,12$ \\
\hline Electricity & 0,729 & $55.891,4$ & 257.405 & $90.881,95$ \\
\hline Light fuel oil & 0,281 & - & - & 739,62 \\
\hline Wood & 0 & - & 0 & - \\
\hline Coal & 0,354 & - & $26.178,3$ & - \\
\hline Heavy fuel oil & 0,279 & - & - & 520 \\
\hline Sum & & $78.046,92$ & $349.097,25$ & $192.279,69$ \\
\hline
\end{tabular}

Based on Table 3 total emission of carbon dioxide is calculated on $619.420 \mathrm{t} \mathrm{CO}_{2}$ in 2008 .

\section{Measures for Reduction of Carbon Dioxide Emission in Residential Buildings}

The last second half of the century has been marked by an enormous consumption of fossil fuels, which is a big problem nowadays. It has let to sudden and significant increase of carbon dioxide concentration in the atmosphere. The problem is that carbon dioxide is a greenhouse gas, and significantly contributes to the process of heating up the Earth, but it should be noted that carbon dioxide is neither the only greenhouse gas, nor the most dangerous one, but it is the widest spread of all. During the 80 s of the 20th century, World became aware of the problem which could strike the entire Earth, so they made 
different laws and measures to slow down the process. Nowadays, the usage of renewable energy is imperative (solar energy, wind, biomass, etc.) in order to achieve a zero emission of greenhouse gases. European Union is very active in emission reduction policy, supporting the usage of renewable energy sources as well as increase of energy efficiency in all areas of human activities. Concerning the usage of energy resources, numerous technical solutions are being implemented, which contribute efficient combustion of fossil fuels with reduced loss and increased level of efficiency. However, at the beginning of the third millennium, with huge technical and technological breakthroughs in many areas, humankind is faced with increasing problems of depletion of fossil fuels, especially minerals, caused by environmental pollution of air, water, soil and faster reduction of forest and agricultural areas. There is an increase in interest for exploration of the natural resources in the conditions of intense technical and economical development, with the aim of attaining sustainability and fulfill the present needs without endangering future generations to fulfill their needs for energy. Aside from reduction of energy consumption by improving energy efficiency in different sectors, it is important to develop more independent, vital and flexible energy system, in which the usage of renewable energy sources could be of a great importance in satisfying needs for energy. In that regard, the usage of alternative and renewable energy sources has been intensified. European commission action plan regarding energy efficiency contains priority measures which include economically viable and energy efficient initiatives, which furthermore include actions in the field of: efficiency of household appliances, energy efficiency in buildings, with an emphasis on promotion of low energy and passive buildings, efficient generation and distribution of energy, introduction of financial mechanisms for energy efficiency as well as for promotion and raising awareness of energy efficiency [11].

Measures for reduction of carbon dioxide emission in residential sector are:

- reduction of heat losses,

- use of solar energy for heating and preparation of domestic hot water,

- use of solar energy for production of electricity,

- use of biomass,

- use of more efficient lighting and household appliances,

- replacement of the conventional boilers with the condensing ones.

\section{Assessment of Future Energy Needs}

Projections of energy consumption in residential sector in Sarajevo Canton estimated based on expected development, as well as demographic projections, macroeconomic indicators and analysis of expected trends.

In residential sector of Sarajevo Canton, energy sources usually used are: electrical energy, natural gas, liquid fuels and solid fuels (coal and firewood). Energy used for the purpose of satisfying needs for heat in the residential sector is proportional to the residential surface of the space. Energy consumption for the preparation of domestic hot water is primarily dependent on the number of occupants in the household. Energy consumption for other demand is not directly related to the surface, but primarily to purchasing power - living standard (cooling, power of electrical appliances, etc.).

In the following text, we analyze expected trends in the residential area of the average household, according to the number of occupants and individual energy consumption in the residential sector of Sarajevo Canton. Expected energy consumption in the residential sector of Sarajevo Canton until 2050 is analyzed on the basis of two scenarios, which present the projections of the future energy consumption in the residential sector of Sarajevo Canton.

\subsection{Scenario I}

In this scenario, the development of energy consumption in the residential area is supposed to be on the same level and of the same proportion like in the previous years, following the energy consumption trend from the period between 2002 and 2012. This scenario suggests the development of energy consumption in line with market trends and the consumer's habits, without any national and/or cantonal intervention, relying on increasing of the residential area of the housing sector in Sarajevo Canton, increasing of population and demography. In 2008, 421.289 people lived in 180.265 residential units in Sarajevo Canton. The total area of the residential space was $11.354 .270 \mathrm{~m}^{2}$, which gives an average apartment floor area of $63 \mathrm{~m}^{2}$.

Assumptions applied in this scenario are:

- Increasing of population in Sarajevo Canton,

- Increasing of GDP/pc,

- Reducing the number of residents per residential units from 2,34 resident/residential unit to 1,7 resident/residential unit,

- Increasing the number of households with the growth rate of $1,7 \%$ annualy,

- The same trend in energy consumption as in the period from 2002 to 2012,

- None of measures for reduction of energy consumption were implemented.

On the basis of human migration from 2003, the projection of the number of inhabitants in Sarajevo Canton has been made for 2050 by the method of trend, Table 4 .

Table 4. Population - projection for 2050 in Sarajevo Canton

\begin{tabular}{llllll}
\hline Years & $\mathbf{2 0 0 8}$ & $\mathbf{2 0 2 3}$ & $\mathbf{2 0 3 0}$ & $\mathbf{2 0 5 0}$ & Growth rate 2003 - 2050 \\
\hline Number of people & 421.289 & 485.484 & 518.704 & 626.680 & 0,95 \\
\hline
\end{tabular}


Table 5. Growth rate for particular energy sources in Sarajevo Canton [9, 10$]$

\begin{tabular}{|c|c|c|c|c|c|c|}
\hline & Heavy fuel oil & Electricity & Natural Gas & Light fuel oil & Coal & Wood \\
\hline & \multicolumn{6}{|l|}{ Growth rate, \% } \\
\hline Residential Buildings & - & 0,58 & $-0,64$ & - & - & - \\
\hline Private houses & - & 2 & $-0,64$ & - & 1,2 & 1,2 \\
\hline District heating system for Households & 0,5 & 0,86 & 0,65 & 0,5 & - & - \\
\hline
\end{tabular}

On the basis of pathway of consumption of energy sources from 2002 to 2012, the projection of consumption of the fuels in the residential sector has been made by the method of trend for the period until 2050. Table 5 shows growth rate for particular energy sources, used for calculations of the required energy for year 2050.

Energy needs are different in residential sector for the households in the private houses and the ones in the residential buildings (collective housing). Table 6 shows expected energy needs for energy in the residential sector for the individual residential facilities (family houses), collective residential facilities not connected to the district heating system and collective residential facilities connected to the district heating system. Expected needs for energy in 2050 are shown in Table 6.

Table 6. Energy consumption estimated by the method of trend in 2050 in residential sector of Sarajevo Canton

\begin{tabular}{|c|c|c|c|c|c|c|c|c|c|}
\hline \multicolumn{2}{|c|}{ Residential buildings [MWh] } & \multicolumn{4}{|c|}{ Private houses [MWh] } & \multicolumn{4}{|c|}{ District heating system [MWh] } \\
\hline Electricity & Gas & Electricity & Gas & Wood & Coal & Electricity & Gas & Light fuel oil & Heavy fuel oil \\
\hline $168.454,8$ & $180.544,2$ & $948.326,4$ & $406.629,7$ & 633.447 & $416.431,8$ & $282.075,6$ & 1.321 .012 & $6.635,9$ & $4.632,6$ \\
\hline
\end{tabular}

It is obvious that the energy needs in residential sector until 2050 will be increased by $61,3 \%$ in collective residential units connected to the district heating plants, by $63,8 \%$ in private houses and by $46,6 \%$ in collective residential units not connected to the district heating plants. Expected increase of population in Sarajevo Canton has also been considered. In case of the same energy mix, the higher increase of energy consumption causes higher increase of carbon dioxide emission.

Table 7 shows the estimated emission of carbon dioxide in the case of increased consumption of energy until 2050.

Table 7. Emission of carbon dioxide by the method of trend in 2050 in Sarajevo Canton

\begin{tabular}{lllll}
\hline \multirow{2}{*}{ Year 2050} & Coefficient of $\mathbf{C O}_{2}$ emissions [t/MWh] & \multicolumn{3}{l}{ Mass of CO2 emitted, [t/a] } \\
\cline { 3 - 4 } & & Residential buildings & Private houses \\
\hline Gas & 0,202 & $36.469,9$ & $82.139,19$ \\
Electricity & 0,729 & $122.803,5$ & $691.329,9$ \\
Light fuel oil & 0,281 & - & - \\
Wood & 0 & - & 0 \\
Coal & 0,354 & - & $87.594,8$ \\
Heavy fuel oil & 0,279 & - & - & $206.844,45$ \\
Sum & & $159.273,4$ & $861.063,9$ \\
\hline
\end{tabular}

Table 7 shows that the total emission of carbon dioxide in 2050 , in the case of increased consumption of energy by the method of trend would be $1.495 .970 \mathrm{t} \mathrm{CO}_{2}$, furthermore the increased emission would be $58,6 \%$ compared to 2008 .

\subsection{Scenario II}

Vision of the energy consumption in Sarajevo Canton is $50 \%$ lower of emitted carbon dioxide in 2050 compared to the present. Both scenarios suppose growth of life standard in Sarajevo Canton, increasing of residential area of the residential sector, as well as the population growth. Unlike the Scenario I, this one suggests development of energy consumption with national and/or cantonal funds, as well as the application of new technical regulations for building of residential facilities; clearly defying the parameters which influence better energy performance of newly built residential facilities. According to the valid legislation in EU countries, the maximum annual energy consumption in buildings is 95 $\mathrm{kWh} / \mathrm{m}^{2}$. Estimation is that an average facility and household in Bosnia and Herzegovina spend twice as much energy then it is usual in EU [12]. Thus, the greatest scope for the increasing of energy efficiency is in housing. It involves a wide range of activities with the final aim of reduction of consumption of all types of energy in the same or similar conditions in the facilities.

Applicable measures for improvement of energy efficiency in housing in Sarajevo Canton are:

- increase of thermal insulation of existing and new buildings (improving of thermal insulation on facade, energy efficient windows etc.),

- increase of efficiency of heating system, cooling and ventilation (energy efficient boilers, insulation of pipes, automatic regulation etc.),

- increase of share of renewable energy sources (solar collectors for domestic hot water system, use of biomass, heat pumps etc.) and

- increase of efficiency of lighting system and electrical appliances.

The current state of energy efficiency in Sarajevo Canton in 
housing can generally be characterized as unsatisfactory, meaning there are significant potentials for energy savings. The average annual specific heat consumption for space heating for the facilities of collective housing is from 125 $\mathrm{kWh} / \mathrm{m}^{2}$ to $152 \mathrm{kWh} / \mathrm{m}^{2}$, meaning that those buildings have an energy rating - E, remarked as buildings with unsatisfactory energy efficiency [13]. Concerning individual housing facilities (family houses), the consumption per square meter is about $250 \mathrm{kWh}$ per year, meaning that those buildings have an energy rating - F. According to the energy performance of buildings in Sarajevo Canton and target values recommended by EU, all the existing facilities should be improved in order to have an energy rating - B until 2050. It is of crucial importance to take care that all new buildings have an energy rating $\mathrm{A}$ or $\mathrm{A}+$. If renovation of the building (installation of insulation, replacement of the openings, replacement of boilers, etc.) reduce energy needs and improve its energy rating from $\mathrm{E}$ into $\mathrm{B}$, the annual energy savings would be $70 \%$ per building for collective housing, and $82 \%$ per facility for individual housing.

The efficiency of heating system can be increased by installing of high - efficient condensing boilers, which would lead to the significant savings in consumption of natural gas because the projected reserve on the surface of heating bodies enables satisfying of thermal comfort, even at lower temperatures of supply pipeline. Modern boilers, under optimum operating conditions have energy efficiency over $90 \%$. In order to increase the efficiency, condensing boilers use latent heat of condensation of water vapor in flue gases, and as a result of this, during the warmer periods of the heating season, they work with efficiency greater by $10-15 \%$ than the traditional boilers [14]. Improvement of efficiency of heating system can be attained with the installation of thermostatic valves acquiring savings in energy consumption from $6-10 \%$. Also, the heat pump can make $10 \%$ of electricity consumption, therefore, the installing of high - efficient heat pump, as well as the optimization of pump system, is an important element for electricity savings, which enables the savings of $80 \%$ [15].

Since the potential of renewable energy sources in Bosnia and Herzegovina is insufficiently used, significant savings in fossil fuel consumption are possible to attain, as well as the reduction of carbon dioxide emission by increasing share of renewable energy sources in a total consumption. Savings in consumption of non - renewable energy sources can be attained by $29 \%$ by installation of solar panels in the facilities of individual housing for the domestic hot water preparation, with the average annual efficiency of $50 \%$ per year [16]. Also, savings in electricity consumption can be attained by $80 \%$ by installing heat pumps for cooling and domestic hot water preparation in the facilities of collective housing. Heat pumps use electricity to divert the heat from the environment to the facility, or to divert the residue of heat from the facility to the environment. Such diverting of the heat requires significantly less energy than other solutions for heating or cooling.

Bosnia and Herzegovina has a remarkable potential of biomass. About $50 \%$ of the territory is covered by forests. Biomass made in agriculture should not be ignored either. However, the share of biomass in the total energy supply is low at the moment. The potentials of residual wood and wood waste are not used, which could ensure the thermal energy for all the facilities of individual housing in Sarajevo Canton. Using the biomass as a fuel for heating of the facilities of individual housing, it is significantly possible to reduce the emission of carbon dioxide in residential sector.

Out of $12,5 \%$ of total electrical energy in households is consumed on lighting. Most efficient measure for improving lighting indoor comfort is to use daylight as much as possible, so, equipping the apartment, the proper selection and arrangement of lighting in functional, as well as in decorative sense, is as important as the selection of furniture and wall paintings [15]. Since daylight is usually insufficient, it is replaced by artificial lighting. According to the EU regulation on lighting products (EC Regulation 244/2009), it is estimated that incandescent light bulbs will not be produced until 2016, and all the light bulbs will be replaced by energy saving ones. Using the energy saving bulbs, the electricity consumption for lighting can be reduced even by $80 \%$ [9]. Electrical devices have a share of about $17,5 \%$ of total electricity consumption in household, and together with appliances, that share is $32,5 \%$. Using more energy efficient appliances, expenses could be reduces to only $10 \%$ of nominal and turning off the appliance instead having it in standby mode is also a way for additional saving. Most of electrical energy used for household appliances (fridge, freezers, washing - machines, drying machines, cookers, etc.) shows that a great number of old and less energy efficient electrical appliances are used in Bosnia and Herzegovina. Energy efficient appliances use less energy (up to $60 \%$ ) compared to the standard ones, so the basic recommendation when purchasing is to strictly pay attention to that, where is economically justified to buy appliances of energy class A or perhaps B. Using the modern energy efficient appliances saves a lot, e.g.: the modern fridge needs up to $55 \%$ less electricity than the model from 1998 . No matter what appliance it is: fridge, washing - machine or dishwasher, the mutual characteristic is that modern appliances use less electrical energy than 10 years ago: combination fridge - freezer up to $60 \%$, dishwasher up to $40 \%$, and washing - machine up to $35 \%$ [15]. Applying these measures of increasing energy efficiency, it is possible to reduce the energy consumption in residential sector in Sarajevo Canton. Table 8 shows the expected needs for energy in 2050 .

Table 8. Energy consumption in 2050 in residential sector in Sarajevo Canton, after applying energy efficiency measures

\begin{tabular}{|c|c|c|c|c|c|c|c|c|c|}
\hline \multicolumn{2}{|c|}{ Residential buildings [MWh] } & \multicolumn{4}{|c|}{ Private houses [MWh] } & \multicolumn{4}{|c|}{ District heating system [MWh] } \\
\hline Electricity & Gas & Electricity & Gas & Wood & Coal & Electricity & Gas & Light fuel oil & Heavy fuel oil \\
\hline 58.264 & 80.304 & $238.212,8$ & $26.419,3$ & $155.911,6$ & 0 & $92.297,7$ & $270.274,8$ & 2.173 & 2.173 \\
\hline
\end{tabular}


Table 9. Emission of carbon dioxide for year 2050 in Sarajevo Canton, after applying energy efficiency measures

\begin{tabular}{lllll}
\hline \multirow{2}{*}{$\mathbf{2 0 5 0}$} & \multirow{2}{*}{ Coefficient of $\mathbf{C O}_{\mathbf{2}}$ emissions [t/MWh] } & \multicolumn{3}{l}{ Mass of $\mathbf{C O}_{\mathbf{2}}$ emitted, [t/a] } \\
\cline { 3 - 5 } & & Residential buildings & Private houses & District heating system \\
\hline Gas & 0,202 & $16.221,2$ & $5.336,6$ & $54.595,5$ \\
Electricity & 0,729 & $42.474,4$ & 173.657 & 67.285 \\
Light fuel oil & 0,281 & - & - & 610,6 \\
Wood & 0 & - & 0 & - \\
Coal & 0,354 & - & 0 & - \\
Heavy fuel oil & 0,279 & - & - & 599,7 \\
Sum & & $58.695,6$ & $178.993,6$ & $123.090,8$ \\
\hline
\end{tabular}

Applying the measures of energy efficiency, the consumption of total energy in 2050 would be $45 \%$ reduced, compared to 2008 , and $78,85 \%$ reduced, compared to energy needs expected by the method of trend for 2050 . So, reduced energy needs would have reduced carbon dioxide emission as a result. Table 9 shows estimated carbon dioxide emission in the case of application already described measures for energy efficiency until 2050. Table 9 shows that the total carbon dioxide emission in 2050, in Scenario II, would be $360.780 \mathrm{t}$ $\mathrm{CO}_{2}$. Reduction of emission of carbon dioxide would be $42 \%$ compared to the base year 2008. In comparison with Scenario I, reduction of emission would be $76 \%$, which can be seen in Figure 5. Using the assumption that the average apartment floor area is $63 \mathrm{~m}^{2}$, with the possible increasing of residential units with growth rate of $1,7 \%$, according to Scenario II, it is estimated that the annual energy consumption would be $72,8 \%$ lower compared to 2008 , and compared to 2050 in Scenario I, the energy consumption would be lower for $78,8 \%$, which would be $40,2 \mathrm{kWh} / \mathrm{m}^{2}$, Figure 6 .

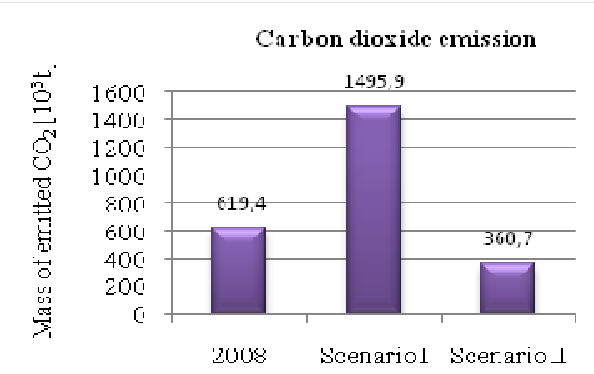

Figure 5. Emission of carbon dioxide for the analyzed scenarios of the energy consumption in residential sector of Sarajevo Canton

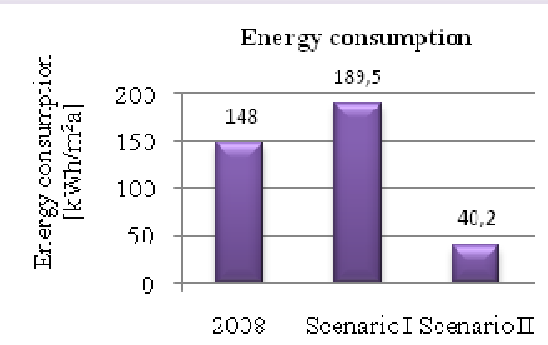

Figure 6. Energy consumption for the analyzed scenarios in residential sector of Sarajevo Canton

In case of implementation of Scenario II, energy consumption in residential sector in Sarajevo Canton will be lower for $3.449 \mathrm{GWh}$ in 2050 than in case of Scenario I.
Bosnia and Herzegovina does not have any commitment to reduce greenhouse gases emission, at least so far. Therefore, the primary driving force for implementation of Scenario II should not be achievement of certain reduction of emission, but, first of all, reduction of energy costs for buildings. Buildings in Sarajevo use mainly natural gas for heating which is imported and very expensive. Annual cost for natural gas is almost $10 \%$ of the cantonal budget. Therefore, any savings would improve overall economy in the Canton. Another benefit of implementation of Scenario II is creation of local jobs. Taking into account that 0,38 job-year is created per GWh of energy saved during implementation of energy efficiency measures [17], it can be calculated that about 65.000 job-year will be created, assuming 20 years of lifetime of energy efficiency measures or about 1.870 sustainable jobs.

\section{Conclusion}

Possible reduction of carbon dioxide emission in residential sector in Bosnia and Herzegovina, with the aim of approaching to "near net zero emission" until 2050, is analyzed in this paper. Two scenarios have been analyzed, applying different assumptions for future energy consumption in residential sector in Sarajevo Canton. Scenario I involves a development of energy consumption on the same level and of the same proportions as in the previous years, following the trend of energy consumption in the period between 2002 and 2012. It was assumed that the population growth rate would be $0,95 \%$ per year, and non measures for reducing of energy consumptions were provided. As the base year 2008 is taken. Measures for improvement of energy efficiency were described in Scenario II, as well as the assumption of increasing of population, mentioned in Scenario I. In Scenario I, the emission of carbon dioxide was analyzed to be higher by $58,6 \%$ for 2050 compared to 2008 and energy consumption per square meter would be higher by $21,9 \%$. Scenario II shows that the emission of carbon dioxide, compared to the base year would be reduced by $42 \%$ and energy consumption per square meter would be reduced by $72,8 \%$. By applications of measures for improvement of energy efficiency while compared to the emission of carbon dioxide in 2050 in Scenario I, it would be reduced by $76 \%$ and energy consumption would be reduced by $78,8 \%$. The results indicate feasibility of achievement of realization of "near net zero emission" vision, establishing appropriate policy and applying technical measures for improvement of energy efficiency, as well as using the potentials of renewable energy sources. 


\section{References}

[1] M. Joshi, S. Ravindranath, G. K. Jain, K. Nazareth, "Sustainable Development: An Introduction", Internship Series, Volume - I, Centre for Environment Education, 2007.

[2] M. Lucic, M. Mack, "qLife", Cotrugli BS, Quantum21.net, Rijeka, No 2/Vol 1/Spring 2009, pp. 5-9, pp. 81-91.

[3] A. Miola, "Backcasting approach for sustainable mobility", JRC Scientific and Technical Reports, European Commission Joint Research Centre, Institute for Environment and Sustainability, European Communities, 2008.

[4] http://www.naturalstep.org/en/backcasting, (Accessed on the 15 th of July 2014).

[5] A. Phdungsilp, "Futures studies' backcasting method used for strategic sustainable city planning", ELSEVIER, Futures 43, 2011, pp. 707-714.

[6] M. Höjer, A. Gullberg, R. Pettersson, „Backcasting images of the future city-Time and space for sustainable development in Stockholm“, ELSEVIER, Technological Forecasting \& Social Change 78, 2011, pp. 819-834.

[7] CETEOR Ltd., "Study on optimal energy supply in Sarajevo Canton", vol 1, Goverment of Sarajevo Canton, 2010.

[8] Institute for development planning of Sarajevo Canton, "Demographic analysis of Sarajevo Canton by city areas from 2003 - 2010", Goverment of Sarajevo Canton, Sarajevo, 2011.
[9] HVAC DESIGN Ltd., REGEA, "Action plan on sustainable energy development of Sarajevo city", Goverment of Sarajevo Canton, Sarajevo, 2011.

[10] Ministry of Agriculture, "Balance of energy needs of Sarajevo Canton", Goverment of Sarajevo Canton, Sarajevo, 2008-2013.

[11] D. Kolic, T. Simunovic, "Economic and ecological characteristics of energy efficient construction", University of Zagreb, Faculty of civil engineering, Zagreb, 2009.

[12] S. Cenic, M. Dakic, A. Husika, "Unlocking the future Sustainable energy in Bosnia and Herzegovina: Challenges and perspectives", Heinrich Böll Foundation, Sarajevo, 2013.

[13] REIC (Regional Education and Information Centre for Dustainable Development in South-East Europe), "Improving energy efficiency of residential buildings in Sarajevo Canton", Center for energy efficiency, Sarajevo, 2009, pp. 70-200.

[14] http://www.computherm-fabo.rs/download/Usteda_energije i _termicka_ugodnost.pdf, (Accessed on the 5th of July 2014).

[15] S. Maksumic, "Analysis of possible measures for reduction of electricity consumption", Training material for energy certification of buildings, CETEOR Ltd., 2011.

[16] http://www.centrala.org.rs/knjiga\%20liber\%20perpetuum/02S unceva_energja_Solar_Energy.pdf, (Accessed on the 12th of July 2014).

[17] M. Ghani-Eneland, M. Renner, A. Chawla, "Low Carbon Jobs for Europe: Current Opportunities and Future Prospects". Gland, Switzerland: World Wide Fund for Nature (WWF), 2009. 